\title{
不完全閉塞による拡張尿管壁の柔軟性に関する実験的研究
}

\author{
秋田大学医学部泌尿器科学教室（主任：土田正義教授） \\ 木 暮 輝 明
}

\section{URETERAL COMPLIANCE OF DILATED URETERS IN DOGS}

\author{
Teruaki Kigure \\ Department of Urology, Akita University School of Medicine \\ (Director: Prof. S. Tsuchida)
}

Compliance and histological findings of dilated ureters in dogs were successively examined after partial ligature. Ureteral compliance was measured by the impedance method using a special probe. This probe, with a balloon at the tip, is equipped with two detecting electrodes and two generating electrodes. Adult mongrel dogs were anesthetized with pentobarbital, and the lower part of the extravesical ureter was partially ligated. At $1,2,4,8,12$, and 26 weeks after ligature, ureteral complicance and histological findings were investigated. Moreover, the closure pressure and the initial cross sectional area of the dilated ureter were measured. The results of the study were as follows:

1) In the dilated ureter, compliance increased gradually for 8 weeks after ligature. However, compliance began to decrease at 12 weeks.

2) The ureteral closure pressure of the normal ureter was statistically higher than that of the dilated ureter.

3) The initial cross sectional area of the normal ureter was statistically lower than that of the dilated ureter.

4) Hypertrophy and hyperplasia of the muscle bundles were found in the dilated ureteral wall.

5) The stellate configuration of the ureteral epithelium almost disappeared 8 weeks after ligature.

6) The proliferation of connective tissues around the muscle bundles was observed 8 weeks after ligature.

7) Ureteral compliance increased in proportion to hypertrophy of the muscle. However, compliance decreased with the increase of the proliferation of connective tissues. These results indicated that the decrease in compliance caused by the proliferation of the connectie tissues was one of the reasons for dysfunction of urine transport in the dilated ureter. Moreover, the value of compliance through the impedance method was considered to be a useful parameter of ureteral function.

\footnotetext{
要旨：雑種成犬の尿管下部に不完全閉塞を作製し，払張した尿管の外径，柔軟性（コンプライアンス）, 閉鎖圧，初期尿管断面積を経時的に測定するとともに，尿管壁の組織学的所見を検討した，尿管のコン プライアンス，閉鎖圧，および初期尿管断面積はインピーダンス法による尿管内圧，断面積同時測定用 のプローブを利用し, 内圧, 容積相関図から求めた。 その結果, 尿管のコンプライアンスは閉塞期間の 延長とともに徐々に上昇し，正常尿管に比べ有意に高くなった。しかし，さらに閉塞期間が延長し， 8 週を経過すると逆に低下する傾向を示した，尿管閉鎖圧は，正常尿管に比べ払張尿管で有意に低下して いた。初期尿管断面積は，扗張尿管に扔いて有意に高値を示していた。尿管壁の組織学的観察では，閉 塞期間の推移に従って尿管粘膜の岈譬構造は消失し内腔は開大した。 また，払張尿管では，平滑筋層の 肥厚は著明となったが, 閉塞期間の延長に伴なって筋束周囲に結合組織の増生が見られるよらになった。 これを払張尿管のコンプライアンスと対比すると，コンプライアンスすなわち尿管の柔軟性は，筋層の 発達とともに高くなり, 結合組織の増生とともに低くなった。
} 


\section{緒 䇺}

尿管は蠕動によって尿 bolus を形成し，腎で分泌さ れた尿を膀胱まで輸送している，尿管が効率よく尿を 輸送するためには，充分な尿 bolus の形成が重要であ り，このためには蠕動によって尿管は収縮し，粘膜は 触襞構造をとって内腔を閉じる必要がある ${ }^{1)}$ ，そして， 充分な尿 bolus が通過するためには尿管壁の適度な柔 軟性が必要である，尿管の蠕動収縮については，尿管 内圧の変化を観察する方法が $\mathrm{Kiil}^{2}{ }^{2}$ にっって，さらに， 蠕動運動を筋電図として検討する方法が土田 ${ }^{3}$ によっ て詳細に報告されている．また，尿管の柔軟性をみる 方法としては, 原田ら ${ }^{4}$ が, 尿管の内圧变化に対する尿 管内腔の容積変化，すなわちコンプライアンスの概念 を尿管に応用している。

一方，種々の原因によって生じた払張尿管に対して 尿路再建術を施行した場合，予後を決定する因子とし て，拡張をきたした原因，尿管閉塞の程度，およびそ の期間を挙げることができる.そして, 術後の尿 bolus の形成能からみると，島田ら5゙が報告しているように， 払張した尿管の器質的变化も尿管機能回復に大きく影 響すると思われる。

そこで, 私は不完全閉塞後の扗張尿管の柔軟性と組 織学的所見が，経時的にどのように推移しているかを 検討するため, 雑種成犬の尿管に不完全閉塞を作製し， 払張した尿管の柔軟性（コンプライアンス）と尿管の 器質的变化を経時的に観察した。

\section{実験対象および方法}

尿管壁の柔軟性をみるため, 原田ら ${ }^{4)}$ は, インピーダ ンス法により正常尿管のコンプライアンスを測定して いる．しかし，彼らが用いたコンプライアンス測定用 プローブは，大きく扗張した尿管に応用した場合，プ ローブ先端の balloon が程み, 測定誤差を生じる可能 性がある，そこで，本研究では，まず，この方法が著 しく払張した尿管にも適用できるかを検討するため以 下のような予備実験を行った。

予備実験：生後 $4 \sim 5$ 年, 体重 $15 \sim 20 \mathrm{~kg}$ の雑種成犬 3 頭を用いて一側尿管に不完全閉塞を作製し， 4 週後 およそ直径 $10 \mathrm{~mm}$ に拡張した尿管と，対側の正常尿管 において尿管コンプライアンス，尿管閉鎖圧，初期尿 管断面積の測定を試みた。

雑種成犬にペントバルビタール $25 \mathrm{mg} / \mathrm{Kg}$ を静注し 仰臥位に固定した後，気管内挿管を行い，レスピレー ター（Aika R-60）で呼吸を管理した。下腹部正中切開 で腹腔に達した後, 後腹膜を剥離し左尿管を露出した。
図 1 実験模式図

雑種成犬の左尿管に不完全閉塞による払張尿管を作 製する.さらに, $1,2,4,8,12,26$ 週後に尿管中部の 内圧，断面積を測定する，測定時には両側に腎瘻を設 置して，腎孟からの尿流の影響を防止する。

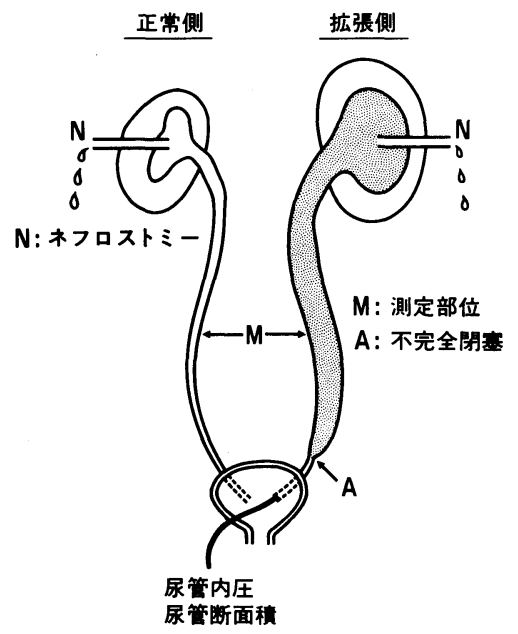

次に, 膀胼尿管移行部の約 $5 \mathrm{~cm}$ 上部で尿管の不完全閉 塞を作製した。この場合，尿管の不完全閉塞の程度を 一定にするため，尿管に沿って24ゲージの注射針を添 えて尿管とともに絧系で結禁してから針だけを引き抜 いた。抗生剤を点滴静注し腹壁を閉じ，4 週後にコン プライアンス測定実験を行った（図 1 ).

麻醉, 体位は上述した不完全閉塞作製時と同様とし, 腹部正中切開を加え，腎，尿管，膀脱を露出した。閉 塞を作製した左尿管の外径を測定した後，尿管を結禁 した絹糸を抜去し閉塞を解除した，次いで腎孟から尿 管への尿流の影響を防止するため，Fr. 4 のポリエチ レンチューブを用いて両側に腎瘻を設置した。膀胱前 壁に粉切開を加え尿管口を露出し，ここより尿管内圧， 断面積同時測定用プローブを逆行性に尿管内に挿入し た，尿管内圧，断面積の測定は，まず正常尿管で，次 いで扗張尿管で行い，測定部位はともに腎孟尿管移行 部と尿管膀胖移行部との中間点とした。

コンプライアンスとは, 膀胱や肺など中腔臓器の圧 力変化に伴う容積変化を表す概念であるが，本実験で は測定する尿管の segment を単位長 $(1 \mathrm{~cm})$ の円筒と 仮定し算出した。すなわち，尿管内圧が $\mathrm{dp}$ 上昇した時 に尿管内腔の容積が $\mathrm{dv}$ ，尿管断面積が ds だけ増加し たとすれば，尿管コンプライフンス (C) は次のように なる. 
図 2 尿管内圧, 断面積同時測定用プローブの模式図 プローブの構造は, Fr. 3またはFr. 4の尿管カテー テルの先端に取り付けた 2 対のインピーダンス測定 電極と，それを覆らシリコンゴムの balloon とから 成る。

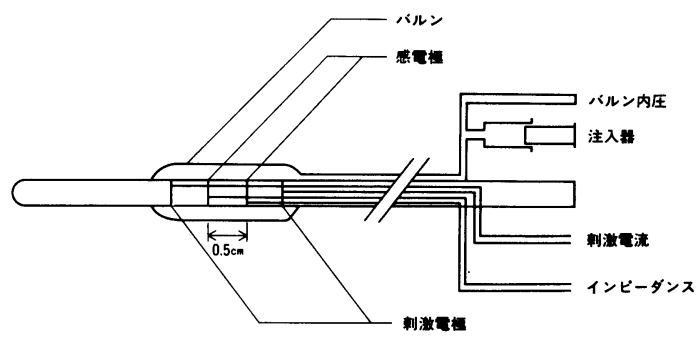

$$
\mathrm{C}=\mathrm{dV} / \mathrm{dP}=1 \cdot \mathrm{dS} / \mathrm{dP}
$$$$
\mathrm{dS} / \mathrm{dP}\left(\mathrm{cm}^{3} / \mathrm{cmH}_{2} \mathrm{O}\right)
$$

今回の実験では尿管内圧, 尿管断面積を求めるため, 原田ら ${ }^{4) 6)}$ の報告したインピーダンス法による尿管内 圧，尿管断面積同時測定用プローブを使用した。この プローブの構造は, Fr. 3 または Fr. 4の尿管カテーテ ルの先端に設置した 2 対のインピーダンス測定電極 と，それを覆らシリコンゴムの balloon とから成って いる(図 2).そして，このプローブの balloon 内に生 理食塩水を一定速度で注入した際のインピーダンスの 変化を, インピーダンスプレチスモグラフ用プレアン プ (日本光電, AI-601G) で測定し，これを除算回路ユ ニット（日本光電, EO-601G）に導いて尿管断面積を レコーダー（日本光電， RM-6000）に記録した。なお, balloon 内への生理食塩水の注入には, Harvard infusion pump（Model 2620）を用い，注入速度は毎時20 $\mathrm{ml}$ とした。尿管内圧の測定には, 圧力トランスジュー サー（Statham, P-50）およびキャリアランプ（日本光 電，AP-601G）を用い，尿管断面積と同時に記録した。

図 3 に予備実験で測定した balloon 内圧と尿管断面 積を示す.この罒に拈いて balloonを介して記録され た内圧は，真の尿管内圧ではなく balloon 固有の張力 と尿管内圧の和を表している，そこで，真の尿管内圧 は, 生理食塩水注入時の balloon 内圧から, 予め大気中 で測定しておいた balloon 固有の内圧を差し引いた值 とした. 蠕動休止期の尿管内圧と尿管容積（断面積 $\times$ $1 \mathrm{~cm})$ の関係を, 測定開始から方眼紙上にプロットする と, 図 4 のよらな相関図が得られた。この図において, 内圧上昇に伴って容積が増加し始める点と, 内圧が上 昇しても容積がほとんど増加しない点を結ぶ回帰直線 ( $\mathrm{Y}=\mathrm{AX}+\mathrm{B})$ の傾き（A）をコンプライアンスとして
図 3 実測した balloon 内圧と尿管断面積 尿管断面積は, balloon 内圧の上昇とともに徐々に増 加するが，しだいに plateau に達する.

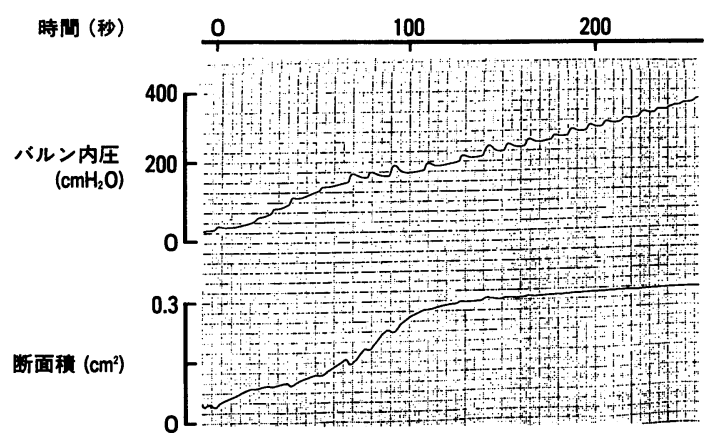

図 4 尿管内圧, 断面積相関図

尿管蠕動休止期の尿管内圧と尿管断面積の関係をプ ロットし, 回㷌直線 $(\mathrm{Y}=\mathrm{AX}+\mathrm{B})$ を描くと, この時 の傾き $\mathrm{A}$ がュンプライアンスを表す。また, $\mathrm{Y}$ 軸との 交点 $\mathrm{B}$ が初期尿管面積を, $\mathrm{X}$ 軸との交点 $-\mathrm{B} / \mathrm{A}$ が尿 管閉鎖圧を示す。

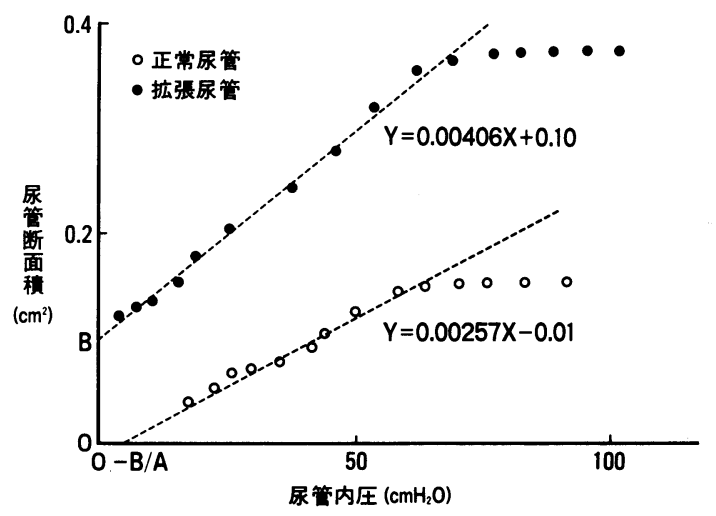

求めた。 また，この回帰直線と $\mathrm{Y}$ 軸との交点は尿管内 圧が $0 \mathrm{cmH}_{2} \mathrm{O}$ の時の尿管容積を示しており, この値 （B）を初期尿管容積とし，（B/1cm）を初期尿管断面積 とした。ささらに, この回㷌直線と X 軸との交点は, 尿 管内に徐々に内圧を加えた場合に初めて容積が増加す る時の圧で, この値 (ーB/A) を尿管の閉塞圧とした。

以上の方法を 3 頭の犬尿管に適用したところ, 断面 積の大きい払張尿管でも支障なくコンプライアンスを 計測でき，さらに尿管閉鎖圧，初期尿管断面積も測定 できることが判明したので，以下のよらな本実験を 行った.

本実験：尿管の不完全閉塞作製方法，および尿管内 圧，断面積の測定手順は，予備実験と同様とした。測 
定時期は，尿管の不完全閉塞作製 1 週後 ( 1 週群), 2 週後 ( 2 週群)，4 週後 ( 4 週群)，8 週後 (8 週群)， 12週後（12週群），26週後 (26週群)，および正常尿管 （コントロール群）とし，各群とれぞれ 5 尿管（5 頭)， 合計35尿管（35頭）を使用した。

尿管内圧, 断面積の測定後に尿管を摘出し, 測定し た部位の尿管について標本を作成し組織学的検討を 行った. 摘出した尿管は $20 \%$ ホルマリンで固定後, 脱 水し, パラフィン包埋を行ってから $5 \mu \mathrm{m}$ の横断切片を 作成した. 次に, Hematoxylin and Eosin 染色, およ びElastica Masson 染色を施行し, 光学顕微鏡低倍率 で観察した。組織学的検討は，まず尿管粘膜の嫂譬の 形態および内腔の大ささを観察した。次いで，尿管壁 および平滑筋層の厚さ, 平滑筋束の太さ, さらに筋束 周囲の結合組織の増生状態について，それぞれを正常 範囲内, 軽度および高度变化の三段階に分類した。な お，尿管壁の厚さについては，コントロール群の平均 值と比較して 1.5 倍未満の場合は正常範囲内 $(-), 1.5$ 倍以上に肥厚したものを軽度肥厚 $(+) ， 2$ 倍以上のも のを高度肥厚 (H) と分類した。平滑筋層の厚さ，お よび筋束の太さは, コントロール群と比較して1.5倍未 満の場合を正常範囲内 (-), 1.5 倍以上のものを軽度 肥厚 $(+), 3$ 倍以上のものを高度肥厚 (H) とした。 結合組織の増生状態は, 個々の筋束の間に細い膠原線 維が入り込んでいるが，正常尿管と同程度であるもの を正常範囲内 (一), 個々の筋束を囲むように結合組織 が存在し, その幅も太くなっているものを軽度增生 $(+)$, 結合組織が個々の筋束間を大きく占拠している ものを高度増生（H）とした。

検討した事項は, 抬張尿管の外径および閉塞解除後 の尿輸送能, 尿管コンプライアンス, 尿管閉鎖圧, 初 期尿管断面積および組織学的所見, さらに尿管コンプ ライフンスと組織学的所見との関係であり, 推計学的
有意差検定にはStudent's t test を用いた。

$$
\text { 成 䋶 }
$$

払張尿管の外径，および閉塞解除後の尿輸送機能： 尿管の外径は, コントロール群では $4.2 \pm 0.8 \mathrm{~mm}$ で あったのに対し， 1 週群では $6.8 \pm 0.8 \mathrm{~mm}$ と有意に高 値を示した $(\mathrm{p}<0.05)$ 。また， 2 週群は $8.0 \pm 1.6 \mathrm{~mm}$, 4 週群 $9.2 \pm 1.6 \mathrm{~mm}, 8$ 週群11.6土2.6mm, 12週群 $12.8 \pm 2.2 \mathrm{~mm}$, および26週群12.6 2 2.8mm と全群で 有意に高値を示した $(\mathrm{p}<0.05)$.

閉塞解除後の尿流状態をみると，4週群以降では腎 孟払張も著明となり，尿の流れは不良で尿管は拡張し たまま円柱状となっていた。

尿管コンプライアンス：正常尿管および払張尿管の コンプライアンスを表 1 に示す。コントロール群の尿 管コンプライフンスは, $(24.3 \pm 8.3) \times 10^{-4} \mathrm{~cm}^{3} / \mathrm{cmH}_{2}$ ○であった。 1 週群， 2 週群では，それぞれ（29.1士 11.9) $\times 10^{-4} \mathrm{~cm}^{3} / \mathrm{cmH}_{2} \mathrm{O},(33.1 \pm 7.3) \times 10^{-4} \mathrm{~cm}^{3} /$ $\mathrm{cmH}_{2} \mathrm{O}$ とコントロール群に比べ高值を示したが有意 な上昇ではなかった。また，4週群，8週群ではそれ ぞれ $(37.2 \pm 5.7) \times 10^{-4} \mathrm{~cm}^{3} / \mathrm{cmH}_{2} \mathrm{O},(50.6 \pm 9.5) \times$ $10^{-4} \mathrm{~cm}^{3} / \mathrm{cmH}_{2} \mathrm{O}$ と推計学的に有意に上昇した $(\mathrm{p}<$ 0.05). しかし, 閉塞期間がさらに延長するとコンプラ イアンスは逆に低下傾向を示し，12週群では（43.9土

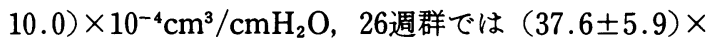
$10^{4} \mathrm{~cm}^{3} / \mathrm{cmH}_{2} \mathrm{O}$ となった. コンプライフンスの変化を 経時的に見ると，図 5 のように尿管の閉塞期間ととも に徐々に上昇し 8 週後にピークを示し, それ以降はし だいに低下した。また，26週群では最高值を示した 8 週群に比べ有意に低下した $(\mathrm{p}<0.05)$.

尿管閉鎖圧および初期尿管断面積（表 1)：尿管閉鎖 压は, コントロール群で2.81 $\pm 5.08 \mathrm{cmH}_{2} \mathrm{O}$ であった。 一方, 払張尿管ではー $13.47 \pm 13.99 \mathrm{cmH}_{2} \mathrm{O}$ (1 週 群), $-11.30 \pm 5.88 \mathrm{cmH}_{2} \mathrm{O}$ ( 2 週群), $-12.51 \pm 7.76$

表 1 払張尿管における尿管コンプライアンス，尿管閉鎖圧括よび 初期尿管断面積 (mean \pm S.D.)

\begin{tabular}{c|c|c|c}
\hline Group & コンプライフンス $\left(10^{-4} \mathrm{~cm}^{3} / \mathrm{cmH}_{2} \mathrm{O}\right)$ & 尿管閉鎖生 $\left(\mathrm{cmH}_{2} \mathrm{O}\right)$ & 初期尿管断面積 $\left(\mathrm{cm}^{2}\right)$ \\
\hline Control & $24.3 \pm 8.3$ & $2.81 \pm 5.08$ & $-0.004 \pm 0.013$ \\
1 week (n=5) & $29.1 \pm 11.9$ & $-13.47 \pm 13.99^{*}$ & $0.050 \pm 0.022^{*}$ \\
2 weeks $(\mathrm{n}=5)$ & $33.1 \pm 7.3$ & $-11.30 \pm 5.88^{*}$ & $0.040 \pm 0.027^{*}$ \\
4 weeks $(\mathrm{n}=5)$ & $37.2 \pm 5.7^{*}$ & $-12.51 \pm 7.76^{*}$ & $0.046 \pm 0.031^{*}$ \\
8 weeks $(\mathrm{n}=5)$ & $50.6 \pm 9.5^{* * *}$ & $-13.43 \pm 3.93^{*}$ & $0.068 \pm 0.024^{*}$ \\
12 weeks $(\mathrm{n}=5)$ & $43.9 \pm 10.0^{* * *}$ & $-15.74 \pm 8.31^{*}$ & $0.068 \pm 0.034^{*}$ \\
26 weeks $(\mathrm{n}=5)$ & $37.6 \pm 5.8^{* *}$ & $-15.46 \pm 5.88^{*}$ & $0.060 \pm 0.029^{*}$ \\
\hline${ }^{*} \mathrm{p}<0.05 \quad{ }^{* *} \mathrm{p}<0.01 \quad{ }^{* * *} \mathrm{p}<0.005$
\end{tabular}


図 5 払張尿管に打けるコンプライアンスの経時的推 移

閉塞期間の延長に伴ってコンプライアンスは上昇し たが 8 週をピークにしだいに低下した。 4 週以降で はコントロール群に比べ有意に高値を示した。最高 值を示した 8 週群と26週群の間にも推計学的有意差 を認めた $(\mathrm{p}<0.05)$.

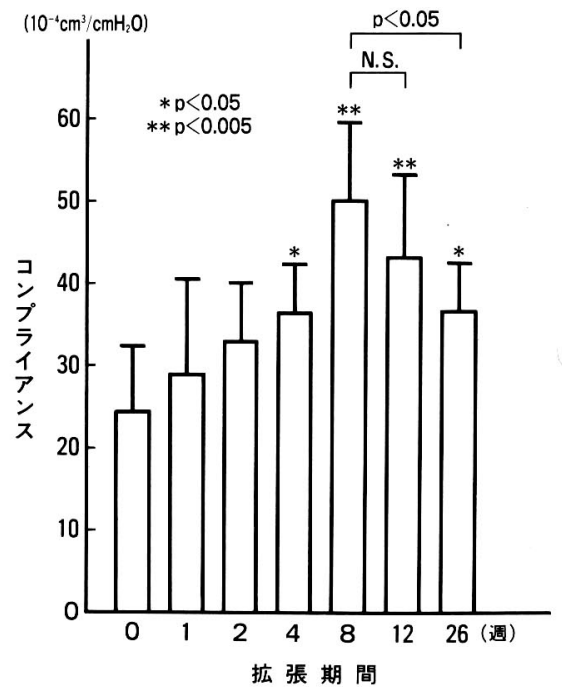

$\mathrm{cmH}_{2} \mathrm{O}$ ( 4 週群), $-13.43 \pm 3.93 \mathrm{cmH}_{2} \mathrm{O}$ ( 8 週群), $15.74 \pm 8.31 \mathrm{cmH}_{2} \mathrm{O}$ (12週群) およびー15.46士5.88 $\mathrm{cmH}_{2} \mathrm{O}$ (26週群) とすべて負の值を示した。 そして,
これら拡張尿管の閉鎖圧は，コントロール群と比較す ると全群で有意に低下していた $(\mathrm{p}<0.05)$.しかし， 拡張尿管それぞれの群の間には推計学的有意差を認め なかった。

初期尿管断面積は，コントロール群がー0.004土 $0.013 \mathrm{~cm}^{2}$ であったのに対し，拡張尿管群ではそれぞれ $0.050 \pm 0.022 \mathrm{~cm}^{2}$ (1週群), $0.040 \pm 0.027 \mathrm{~cm}^{2}$ ( 2 週群), $0.046 \pm 0.031 \mathrm{~cm}^{2}$ ( 4 週群), $0.068 \pm 0.024 \mathrm{~cm}^{2}$ （8 週 群), $0.068 \pm 0.034 \mathrm{~cm}^{2}$ (12週群), および $0.060 \pm 0.029$ $\mathrm{cm}^{2}$ (26週群)であった。そして，これら拡張尿管では， 全群でコントロール群よりも有意に高值を示した $(\mathrm{p}<0.05)$. しかし，拡張尿管群それぞれの間には推計 学的有意差を認めなかった。

組織学的所見：コントロール群の尿管では, 粘膜は 星形の媰譬を形成し腔内に突出していた（図 6A)。壁 の厚さは600 900 $\mu \mathrm{m}$, 平滑筇層の厚さは250 400 $\mu \mathrm{m}$, 筋束の太さは $50 \sim 100 \mu \mathrm{m}$ であった。筋束の走行 は, 外側には輪走を示すものが多く, 内側には縦斜走 筋束が多く見られた。 また，個々の筋束の間には細い 膠原線維を少量ながら認めた。

拡張尿管では, 閉塞期間の延長に伴って粘膜の腔内 への星形の突出は変形し, 8 週群以降では，13尿管中 9 尿管で星形の龾譬は消失し内腔は丸く開大していた (図 6B). 尿管壁の厚さ, 筋層の厚さ, 筋束の太さ，括 よび笳束間の結合組織の増生状態についておのおの正

図 6 尿管粘膜の皺譬構造

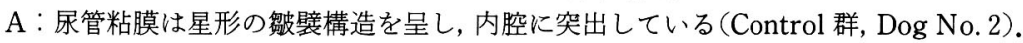

B：尿管粘膜の媰譬構造は消失し，内腔は開大している（12週群，Dog No. 1).
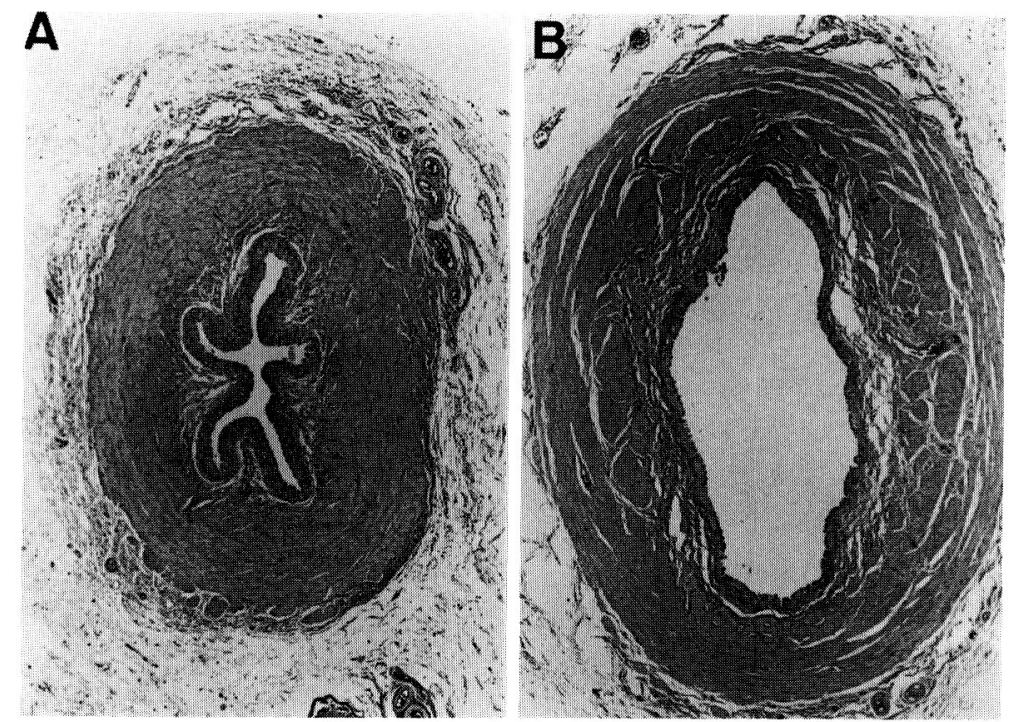
図 7 平滑筋層の肥厚程度からみた分類

A：正常 (一) 筇㬝の厚さは250 $400 \mu$ を示す. B：軽度肥厚 $(十)$ 筋層の厚さは正常 群の 1.5 倍以上を示す. $\mathrm{C}$ : 高度肥厚 (H) 筋層の厚さは正常群の 3 倍以上を示す.
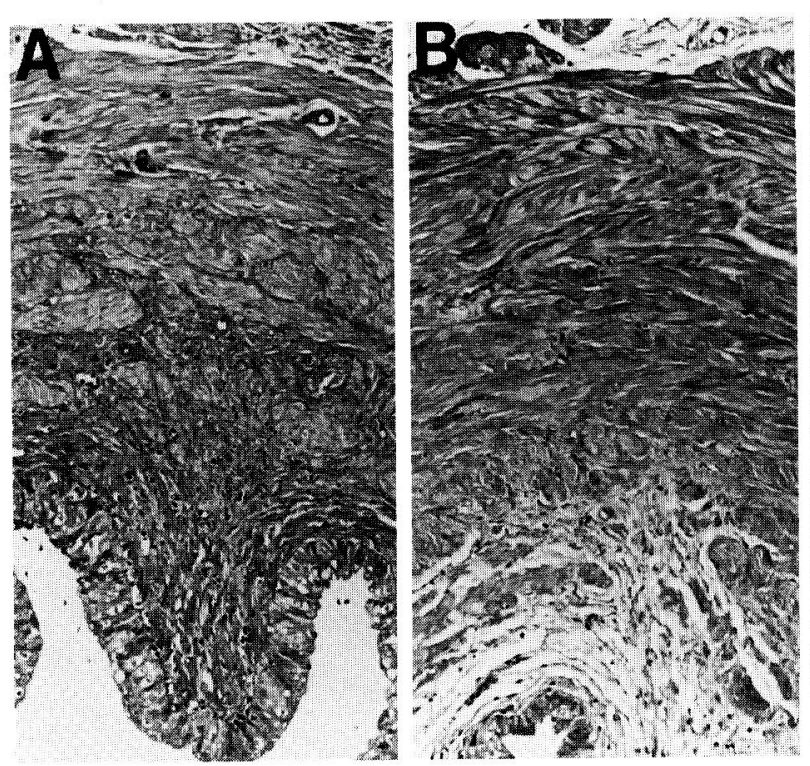

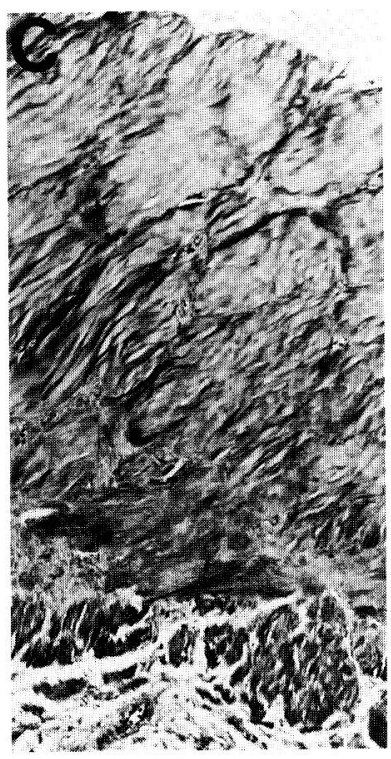

常範囲, 軽度变化, 高度变化の三段階に分け, 各段階 に該当する尿管数を表 2 に示した，尿管壁の厚さは， 1 週群では 5 尿管中 2 尿管は正常群とほぼ同様であっ たが， 3 尿管に軽度の肥厚を認め， 2 週群， 4 週群で は，4 尿管ともにすべて肥厚を示し，そのらち 2 尿管 は高度肥厚であった。閉塞の期間がさらに延長し，8， 12，26週群になると壁は全尿管で高度肥厚を示した。 平滑筋層の厚さは, 1 週群では 5 尿管中 3 尿管は正常 (図 7A)，2 尿管は軽度肥厚を示し(図 7b)，2 週群で は 4 尿管中 3 尿管に軽度肥厚を認めた。ささに閉塞期 間が延長すると筋層の肥厚も進み, 26 週群では 4 尿管 中 3 尿管に高度肥厚を認めた (図 7C). また, 筋束の肥 大も閉塞期間の延長に伴って進行し， 8 週群からは 1 尿管を除き全ての尿管に高度肥大を認めた(図 7C). 一 方, 結合組織の増生状態について見ると， 1 週群， 2 週群では全ての尿管がコントロール群と同様, 増生は 認められなかった（図 8A)。4 週群，8週群になると 結合組織の軽度増生を示す尿管が見られるようになっ た（図 8B）。さらに12週群になると結合組織の増生も 進行し, 26 週群では 4 尿管中 2 尿管に高度增生(図 8C) を，1尿管に軽度増生を認めた。

コンプライアンスと尿管壁の組織学的所見との関 係：図 9 に平滑筋層の肥厚程度とコンプライアンスの 関係を示した。筋層正常の尿管コンプライアンスは,
(26.1 \pm 7.2$) \times 10^{-4} \mathrm{~cm}^{3} / \mathrm{cmH}_{2} \mathrm{O}$ であったのに対し，軽 度肥厚を示与尿管では $(38.6 \pm 11.6) \times 10^{-4} \mathrm{~cm}^{3} / \mathrm{cmH}_{2}$ $\mathrm{O}$, 高度肥厚を示すものでは $(44.3 \pm 8.6) \times 10^{-4} \mathrm{~cm}^{3} /$ $\mathrm{cmH}_{2} \mathrm{O}$ と徐々に上昇し, 高度および軽度肥厚群と正 常群との間には推計学的有意差を認めた $(\mathrm{p}<0.05)$.

一方, 筋層の肥厚に伴って上昇したコンプライアンス 值は, 12週以降になると結合組織の増生が進行する(表 2) とともに低下していた（図 5 ).

\section{考 察}

著しく拉張した尿管では，尿管の閉塞が解除されて も尿輸送が円滑に行なわれないと報告されている5. 今回の実験でも，不完全閉塞 4 週後では，尿管を結紮 した絹糸を抜去しても尿管は拡張したますで，尿管機 能は障害されていた，拡張した尿管の尿輸送効率が低 下する原因について，Bäcklund ら $ら^{7)}$ ，拡張尿管に pressure flow study を行い，蠕動休止期の基礎圧が低 く，蠕動収縮の際の内圧上昇も小さかったと報告して いる、しかし，これとは反対に，高度に拡張した尿管 であっても，正常もしくはそれ以上の收縮力を示した とする報告も見られ788, 拡張尿管の尿輸送障害の機構 は明らかではない。

土田9), 原田ら ${ }^{101}$ は, 先天性水腎症抢よび正常尿管の bolus volume を測定し，正常な尿管では，腎での尿分 泌量が増加した場合，尿管の蠕動頻度も増加するが, 
図 8 結合組織の増生状態からみた分類

A：正常 (一)個々の筋束間に結合組織がごく僅かに認められる. B : 軽度增生 $(+)$ 筋束を取り囲むように結合組織が存在し，その幅は正常群に比べ太い，C：高度増生 （十）個々の筋束の間を結合組織が大きく占拠している.
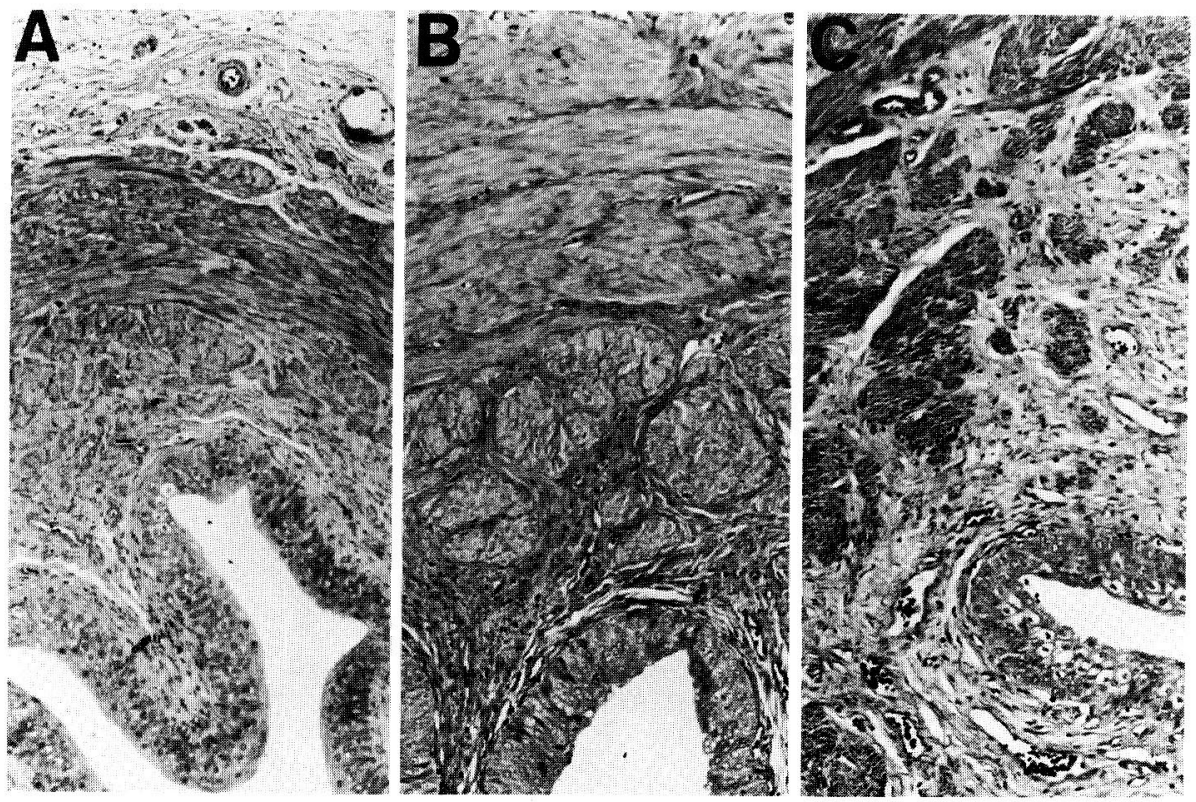

図 9 筋層の肥厚とコンプライアンスとの関係

筋層の肥厚が進むにつれてコンプライアンスは上昇 し, 筋層肥厚を示す尿管と正常尿管の間には推計学 的有意差を認める。

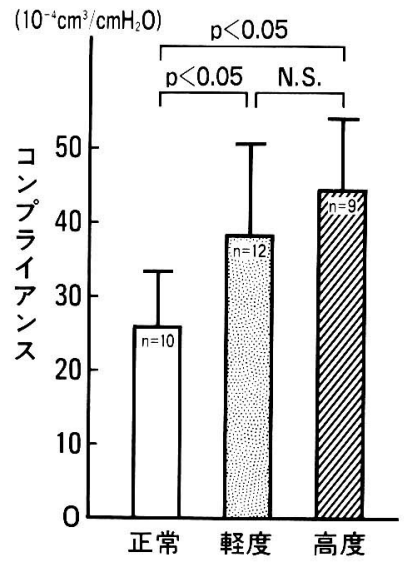

筋層の肥厚

1 個あたりの bolus volume が著しく増加し対応して いると述べている。これに対し，先天性水腎症では， 拡張した腎孟に pig tail 状の尿管が付着しているため 充分な bolus を作ることがでさないと報告している。
表 2 㽷管壁の組織学的変化による分類

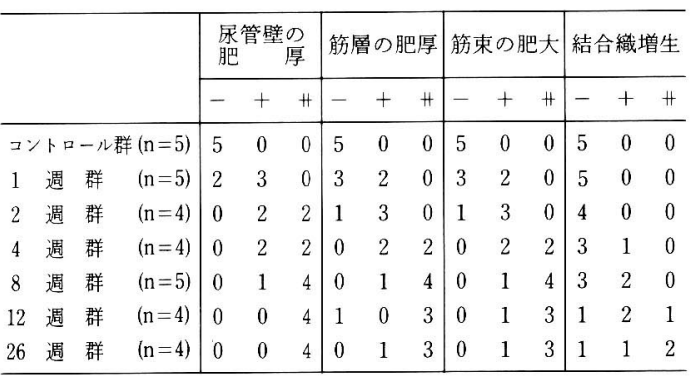

各要素についてそれぞれ 3 段階 $(-$ : 認めず, +：中等度, + ：

高度) に分類し，それらに該当する尿管数を示した。

そして，尿管が充分な機能を発揮するには，漏斗状を 示す腎孟尿管移行部の形態, 尿管壁の適度な柔軟性, 扣よび蠕動に伴う完全な収縮輪の三要素が重要である と報告している，また，Woodburne ら ${ }^{1)}$ は，蠕動収縮 時に尿管壁が密着する必要があり，このためには尿管 粘膜は星形の㱀譬を呈し内腔に突出することが重要で あると述べている。

これらの因子について, 今回の実験結果を検討する。 まず，腎孟尿管移行部の形態についてみると，不完全 閉塞後の尿管拉よび腎孟は尿が充満し著しく抎張して 
いたが，腎孟尿管移行部は基本的には漏斗状を呈して 扣り，尿管の屈曲蛇行なども認めなかった，尿管壁の 柔軟性については, 不完全閉塞の初期の尿管では正常 尿管よりもコンプライアンス值は高くなっていた。し かし, 閉塞期間が 8 週を過ぎると壁の線維化が進行し コンプライアンスは低下していた。コンプライアンス が低下すれば尿管壁は柔軟性を失い，大きな尿 bolus を作ることが難しくなり尿管機能は低下寸ると考号ら れる。尿管の蠕動に伴う収縮輪，および尿管壁の密着 性については, 今回の実験では, Woodburne ら ${ }^{1)}$ が報 告しているょうに，正常尿管の粘膜は星形の㱀璧を形 成して内腔をほぼ密着させていた。しかし, 払張尿管 では, 閉塞の期間とともに㱀譬の形態は徐々に変形し, 8 週群以降では㱀譬構造は消失し内腔は円状に開大し ていた。このことは，拡張尿管では蠕動收縮時に粘膜 壁が密着しにくく, 完全な収縮輪は形成されないため, 充分な尿 bolus は作れなかったと推定される.

今回検討した尿管閉鎖圧，すなわち内圧を上昇させ ていき初めて尿管断面積が増加し始める時の内圧は, 正常尿管では, $2.81 \mathrm{cmH}_{2} \mathrm{O}$ と陽圧を示したのに対し, 拡張尿管では全て陰圧を示していた。すなわち，拡張 した尿管では，内圧が陰圧となった時に初めてその内 腔を閉鎖できることを意味している。ささら，尿管内 圧が $0 \mathrm{cmH}_{2} \mathrm{O}$ の時の尿管断面積は, 拡張尿管で常に正 の值を示していた。これらの結果から, 正常尿管では, 本来, ある tonus で内腔は閉じており, bolus の通過に よって内腔は一旦開くが, 蠕動収縮後は再び壁が密着 し閉鎖するのに対し，拡張尿管では，内圧がほとんど かからない状態でも内腔は開いて拈り，一本の column 状となっていることを示している。このように尿 管内腔が常に開いた状態にあれば，蠕動収縮時にも尿 管壁は密着しにくく，有効な bolus が形成されないで あろう。以上のように, 拡張尿管の尿輸送障害は, 尿 管壁の器質的变化による壁の柔軟性の低下, および粘 膜の皺譬構造消失に伴う壁の密着不良と収縮輪形成障 害によるものと推定される。

今回は, 拡張尿管の尿輸送動態が閉塞の解除によっ て回復するかぞうかの検討は行っていないが，一般に 結石などによる尿管閉塞は, 早期に解除すれば尿管は 充分機能を回復することが知られている。しかし，高 度な拡張尿管の尿輸送障害を治療する際には, 拡張の 原因を解除するとともに，尿管を縫縮する必要がある と報告されている ${ }^{1112)}$ ，尿管が効率良く尿を輸送する には, 蠕動収縮時に尿管壁が密着する必要があること
を考えると，尿管の縫縮は合理的と言える。しかし， このような方法で治療した場合，たと六同じ原因で同 じ程度に拡張した尿管であっても，予後に大きな違い がでてくる。この理由の一つとして島田ら5) た尿管自体の器質的变化の相違を挙げている。すなわ ち，尿管壁に高度な線維化が見られるようになった尿 管は，その形態を修復しても尿輸送は改善されなかっ たと報告している。

一方，尿管閉塞後の拡張した尿管には，平滑筋の肥 大や結合組織の増生が二次的变化として認められると の報告が多い13) 15). 今回の実験でも, 閉塞期間の比較 的早期には平滑筋の肥厚や筋束の肥大が著明となり, しかも，その時のコンプライアンスは正常よりも高値 を示していた。しかし，閉塞期間が 12 週以降になると 筋束周囲に結合組織の増生が顕著になり拡張尿管のコ ンプライフンスは低下していた，以上の成績から，尿 管閉塞後の拡張尿管は, 結合組織の増生が始まる以前 に閉塞を解除すれば，尿管機能の回復を期待できると 考えられる。また，今回の実験で施行した尿管コンプ ライアンスの測定は, 閉塞解除後の尿管機能を判定す るらえで臨床的にも有用と考えられた。

\section{結 論}

雑種成犬の下部尿管に不完全閉塞を作製し, 拡張し た尿管のコンプライアンス, 閉鎖圧, 初期尿管断面積 を計測し, 併せてこの時の尿管壁の組織学的所見を観 察した。そして，これらが閉塞期間によってどのよう に変化するか検討したところ次の結果を得た。

1）払張した尿管のコンプライアンスは, 閉塞期間の 延長とともに有意に上昇した。しかし，8週をピーク にその後は徐々に低下した。

2）拡張した尿管の閉鎖圧は, 正常尿管に比べ有意に 低值を示した。

3）初期尿管断面積は, 拡張尿管に拈いて常に正の値 を示した。

4) 閉塞期間の延長に伴い尿管粘膜の貱譬構造は消 失し, 尿管平滑筋層の肥厚, 筋束の肥大が認められた。 閉塞期間がさらに延長すると, 筋束周囲には膠原線維 を主体とする結合組織の増生が顕著になった。

5）尿管のコンプライアンスすなわち柔軟性は, 尿管 平滑筋の発達に伴って上昇し, 結合組織の増生にした がって低下傾向を示した。

以上の結果から, 拡張尿管の尿管機能低下の原因々 して, 尿管壁の器質的変化による柔軟性（コンプライ アンス）の低下, 粘膜の蚼譬構造の消失による壁の密 
着能低下と蠕動時の収縮輪形成障害が推定された。そ して, コンプライアンスの測定は, 閉塞解除後の尿管 機能を判定するらえで臨床的にも有用と考えられた。

稿を終えるにあたり, 御指導, 御校閲を賜った恩師土田正 義教授に深甚なる謝意を表します。 また, 直接御指導, 御助 言を頂いた原田 忠講師をはじめ教室員諸兄に深く感謝し ます。

なお，本論文の要旨の一部は第28回日本平滑筋学会総会 （東京）に於て発表した。

\section{文献}

1) Woodburne, R.T. and Lapides, J.: The ureteral lumen during peristalsis. Am. J. Anat., 133, 255-258, 1972.

2) Kiil, F.: Physiology of the renal pelvis and ureter. in Urology, Campbell, M.F., 4th. ed. p. 55 -86, Sanders Co., Philadelphia, 1978.

3）土田正義：生体尿管筋電因. 日平滑筫誌，6，1-14, 1970.

4）原田 忠, 熊崎 匠, 餌取和美, 宮形 滋, 土田正 義：Impedance 法による尿管コンプライアンス および尿管断面積測定. 日平滑筋誌, 21, 290-292, 1985.

5）島田憲次, 寺川知良, 岡本新司, 生駒文彦：小児に 扣ける高度払張尿管の組織学的検討. 小児外科, 13, 109-114, 1981 .

6）原田 忠, 宮形 滋, 慨取和美, 熊崎 匠, 能登宏 光: Impedance Urine Bolusmetry (bolus volume および frequency 測定）による腎孟尿管機能 の評価。日平滑筋誌，20，445-453， 1984.

7) Băcklund, L. and Reuterskiold, A.G.: The abnormal ureter in children. I. Perfusion studies on the wide non-refluxing ureter. Scand. J. Urol. Nephrol., 3, 219-228, 1969.

8) Hausmann, M., Biancani, P. and Weiss, R.M.: Length-tension characteristics of obstructed rabbit ureter. Physiologist, 17, 241, 1974.

9）土田正義：堅孟尿管機能面からみた腎孟形成術の 検討. 日泌尿会誌, 73, 1-9, 1982.

10）原田 忠, 森田 隆, 西沢 理, 能登宏光, 土田正 義：Bolus volume 測定による堅孟, 尿管機能の検 討一先天性水堅症に対する術前, 術後の機能評価 一。 日泌尿会誌，74，1370-1382，1983.

11) Rabinowitz, R., Barkin, M., Schilinger, J.F., Jeffs, R.D. and Cook, G.T.: The influence of etiology on the surgical management and prognosis of the massively dilated ureter in children. J. Urol., 119, 808-813, 1978.

12) Bjordal, R., Eek, S. and Knutrud, O.: Early reconstruction of wide ureter in children. Urology, 11, 326-337, 1978.

13) Tanagho, E.A., Smith, D.R. and Guthrie, T.H.: Pathophysiology of functional ureteral obstruction. J. Urol., 104, 73-88, 1970.

14) Cussen, L.J.: The morphology of congenital dilatation of the ureter: Intrinsic ureteral lesions. Aust. N.Z.J. Surg., 41, 185-194, 1971.

15) Hanna, M.K., Jeffss, R.D., Sturgess, J.M. and Barkin, M.: Ureteral structure and ultrastructure. Part II. Congenital uretero-pelvic junction obstruction and primary obstructive megaureter. J. Urol., 116, 725-730, 1976.

（1989年 2 月 13 日受理, 特別揭載） 